UDC $577.29+612.73$

doi: https://doi.org/10.15407/ubj88.05.048

\title{
CALIX[4]ARENE C-90 AND ITS ANALOGS ACTIVATE ATPase OF THE MYOMETRIUM MYOSIN SUBFRAGMENT-1
}

\author{
R. D. LABYNTSEVA ${ }^{1}$, O. V. BEVZA $A^{1}$, K. V. LYTVYN ${ }^{1}$, M. O. BOROVYK ${ }^{1}$, \\ R. V. RODIK ${ }^{2}$, V.I. KALCHENKO', S. O. KOSTERIN ${ }^{1}$ \\ ${ }^{1}$ Palladin Institute of Biochemistry, National Academy of Sciences of Ukraine, Kyiv; \\ e-mail: labyntseva@biochem.kiev.ua; \\ ${ }^{2}$ Institute of Organic Chemistry, National Academy of Sciences of Ukraine, Kyiv; \\ e-mail:vik@ioch.kiev.ua
}

\begin{abstract}
Numerous female reproductive abnormalities are consequences of disorders in uterus smooth muscle (myometrium) contractile function. In this work, we described activators of ATPase, which could be used for development of effective treatments for correcting this dysfunction. Myosin ATPase localized in the catalytic domain of myosin subfragment-1 transforms a chemical energy deposited in macroergic bonds of ATP into mechanical movement. It was shown that calix[4]arene C-90 and its structural analogs functionalized at the upper rim of macrocycle with four or at least two N-phenylsulfonyltrifluoroacetamidine groups, are able to activate ATP hydrolysis catalyzed by myometrium myosin subfragment-1. It was shown with the method of computer modeling that $N$-phenylsulfonyltrifluoroacetamidine groups of calix[4]arene C-90 interact with responsible for binding, coordination and the hydrolysis of ATP amino acid residues of myosin subfragment-1. The results can be used for further research aimed at using calix[4]arene C-90 and its analogs as pharmacological compounds that can effectively normalize myometrium contractile hypofunction.
\end{abstract}

Ke y words: myosin subfragment-1, ATPase activity, calix[4]arene C-90, docking, myometrium smooth muscles.

$\mathrm{M}$ yometrium contractile function is associated with the activity of the main structural and contractile protein of uterus smooth muscle - actomyosin, in which myosin exhibits enzyme activity, namely the ability to hydrolyze ATP. Myosin ATPase, localized in the catalytic domain of subfragment-1 ( $\mathrm{S} 1$ or head), is called a biomolecular motor. It uses the free energy of ATP hydrolysis deposited in ATP macroergic bonds for cyclic changes in the structure of the myosin head. The conformational changes in myosin active site due to ATP hydrolysis are enhanced with the assistance of switch 1, switch 2, relay and converter and transferred to the regulatory domain - lever arm, which plays an essential role in the generation of force and movement [1-3]. As a result, myosin moves along the actin filament causing the muscle contraction. That is why myosin catalyzed ATP hydrolysis is considered as one of the most important processes in the molecular mechanism of the myometrium contraction.
The known pathologies of uterus contractile function (weak labor contraction, preterm birth, miscarriage, atony, hypo- and hypertonicity of the uterus, etc.) occur due to the uterine smooth muscle contraction-relaxation dysfunction [4].Therefore, it is vital to develop new effective pharmacological substances capable of normalizing uterine function. The molecular basis for designing potentially bioactive compounds could be calix[4] arenes - synthetic macrocyclic phenol oligomers, which have a cup-shaped structure with various (by their chemical nature) substituents at the upper and lower rims. Calix[4]arenes formed by four functionalized arene fragments are characterized by rather a flexible macrocycle conformation, low toxicity of the matrix and the ability to penetrate into the cell. All these properties make calix[4]arenes promising agents for developing new effective drugs $[5,6]$.

Calix[4]arenes are able to modify the functional activity of certain proteins, particularly the activity of enzymes. We have previously shown that calix[4]a- 
rene C-90 (5,11,17,23-tetra(trifluoromethyl(phenylsulfonylimino))-methylamino-25,26,27,28-tetrapropoxy-calix[4]arene) at concentration of $100 \mu \mathrm{M}$ activated ATPase of the myometrium actomyosin complex more than 2-fold [7]. Veklich et al. [8] showed that $100 \mu \mathrm{M}$ calix[4]arene C-90 effectively (by $75 \%$ relative to control) inhibited the activity of $\mathrm{Ca}^{2+}, \mathrm{Mg}^{2+}$-ATPase in the fraction of uterus plasma membrane myocytes, and practically did not affect the activity of $\mathrm{Mg}^{2+}$-independent $\mathrm{Ca}^{2+}$-dependent ATPase, $\mathrm{Na}^{+}, \mathrm{K}^{+}$-ATPase and $\mathrm{Mg}^{2+}$-ATPase localized at the same membrane structure.

The aim of this study was to investigate the effect of calix[4]arene C-90 and its structural analogs, such as calix[4] arenes C-956, C-957, C-960, C772, C-716, C-715, as well as the calix[4]arene cup itself without substituents (C-150), and the structural fragment of the C-90 molecule - N-(4-ethoxyphenyl)$\mathrm{N}^{\prime}$-(phenylsulfonyl)-trifluoromethylacetimidoamide (M-1) on the ATPase activity of myosin S1, which is a myosin catalytic unit, isolated from uterine smooth muscle. Using computer modeling we investigated the mechanisms of action of calix[4]arene C-90 and its analogs on the hydrolytic activity of myosin S1.

\section{Materials and Methods}

Preparation of actomyosin was obtained from swine uterus smooth muscle by the modified Barany method [9]. Preparation of myosin S1 was obtained from swine actomyosin by the modified Suzuki method [10]. The purity of the samples was controlled by PAAG-SDS electrophoresis [11].

ATPase activity of myosin $\mathrm{S} 1$ was determined in a 96-well plate at $37{ }^{\circ} \mathrm{C}$ in an incubation medium (total volume $0.1 \mathrm{ml}$ ) of the following composition $(\mathrm{mM})$ : tris- $\mathrm{HCl}$ buffer $(\mathrm{pH} 7.2)-20, \mathrm{KCl}-100$, $\mathrm{CaCl}_{2}-0.01, \mathrm{MgCl}_{2}-5$, ATP -3 (standard conditions). Protein (myosin S1) concentration was $20 \mu \mathrm{g} /$ $\mathrm{ml}$. Incubation time was $5 \mathrm{~min}$. Samples containing all components of the incubation medium without myosin S1 were taken as control of non-enzyme ATP hydrolysis. The amount of inorganic phosphate cleaved from ATP during hydrolase reaction was determined by the Chen method [12], by measurement of optical absorbance of the solution at $820 \mathrm{~nm}$ using a microplate reader $\mu$ Quant (Biotek Instruments,

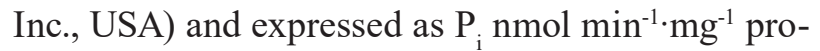
tein.

In the experiments on the effect of calix[4]arenes on the ATPase activity of myosin S1 we used standard incubation medium, to which $10 \mu \mathrm{l}$ of a $1 \mathrm{mM}$ solution of calix[4]arenes (to a final concentration of $100 \mu \mathrm{M}$ ) was added. The value of ATPhydrolase activity in the absence of calix[4]arenes in the incubation medium was taken as $100 \%$ ( 0 point).

Calix[4]arene C-90, its analogs, as well as calix[4]arene cup (C-150) and the model structure M-1 (Fig. 1) were synthesized and characterized using NMR techniques and IR spectroscopy in the Phosphoranes Chemistry Department of the Institute of Organic Chemistry, NAS of Ukraine headed by Corresponding member NAS of Ukraine Prof. V. I. Kalchenko. Synthesis of calix[4]arene C-90 has been described previously [13, 8]. Calix[4]arene studied in the work:

C-90 (5,11,17,23-tetra(trifluoromethyl(phenylsulfonylimino))-methylamino-25,26,27,28-tetrapropoxycalix[4]arene);

C-772 (5,11-di(trifluoromethyl(phenylsulfonylimino))-methylamino-17,23-di-tert-butyl-26,27-dipropoxycalix[4]arene);

C-716 (5,17-di(trifluoromethyl(phenylsulfonylimino))-methylamino-11,23-di-tert-butyl-25,27-dipropoxycalix[4]arene);

C-960 (5,17-di(trifluoromethyl(phenylsulfonylimino))-methylamino-26,28-dihydroxy-25,27-dipropoxycalix[4]arene);

C-957 (5,11,7-tri(trifluoromethyl(phenylsulfonylimino))-methyl-amino-23-tert-butyl-26,28-dihydroxy-25,27-dipropoxycalix[4]arene);

C-956 (5,11,17,23-tetra(trifluoromethyl(phenylsulfonylimino))-methylamino-25,27-dioctyloxy-26,28dipropoxycalix[4]arene);

C-150 (26,28-dihydroxy-25,27-dipropoxycalix[4]arene);

M-1 (N-(4-ethoxyphenyl)-N'-(phenylsulfonyl)trifluoromethylacetimidoamide);

C-715 5,17-di(trifluoro)acetamido-11,23-di-tert-butyl-26,28-dihydroxy-25,27-dipropoxycalix[4]arene.

Calix[4]arenes were dissolved in dimethylsulfoxide (DMSO) and diluted with water to the desired concentration. Compound M-1 was dissolved in water.

The apparent activation constants $K_{\mathrm{a}}$ and Hill coefficients $n_{\mathrm{H}}$ were calculated using the concentration dependence of calix[4]arenes effect on the ATPase activity of myosin S1, plotted in logarithmic coordinates according to the linearized Hill equation:

$$
\log \left[\left(V_{\max }-V\right) /\left(V-V_{0}\right)\right]=n_{\mathrm{H}} \log K_{\mathrm{a}}-n_{\mathrm{H}} \lg A,
$$

where $V$ is specific enzyme activity, $V_{0}$ is specific enzyme activity in the absence of activator in the 
$A$

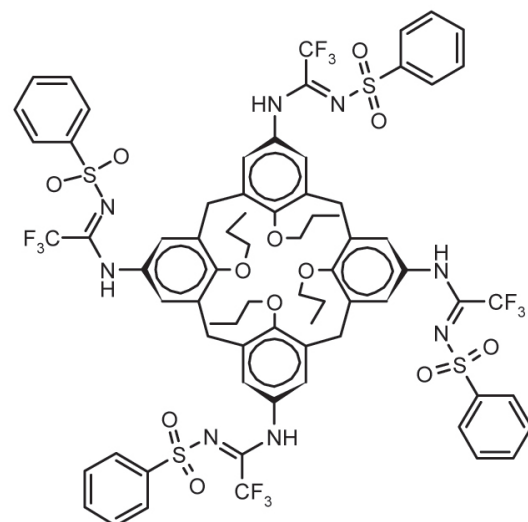

C-90

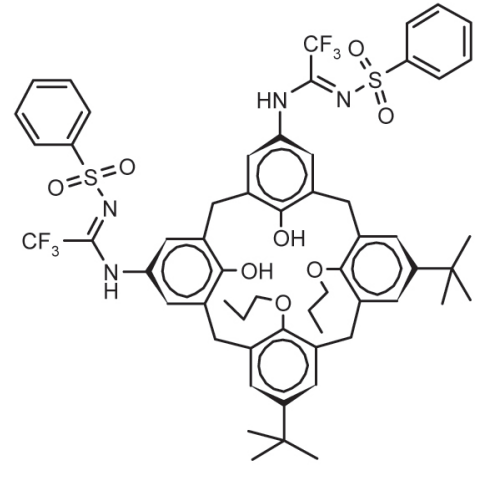

C-772

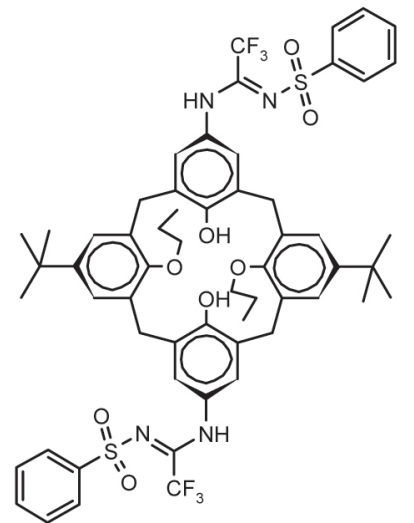

C-716



C-960

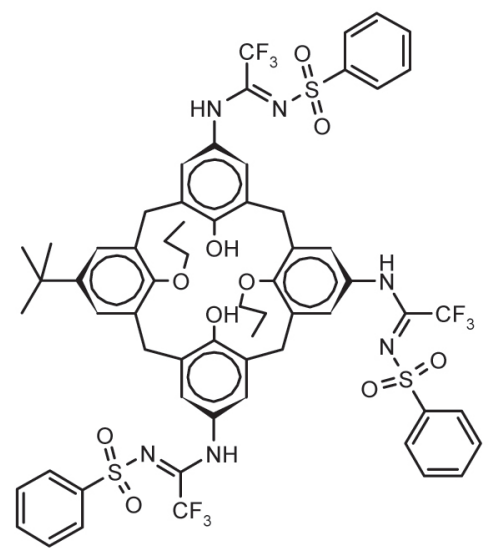

C-957

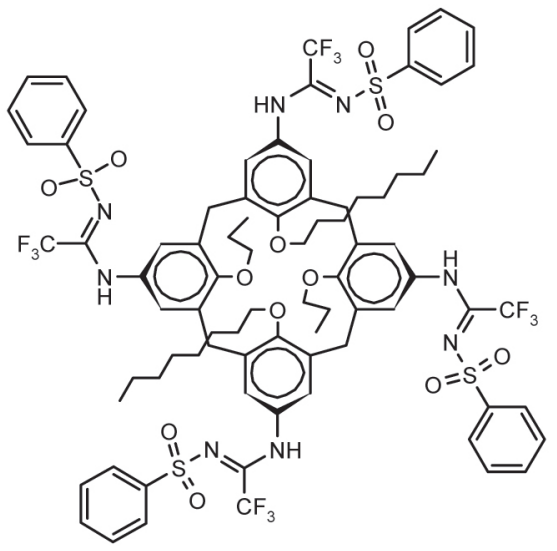

C-956

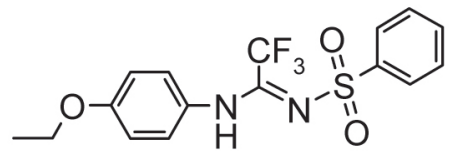

$M-1$

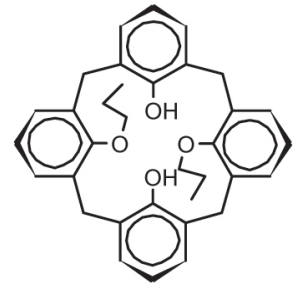

C-150

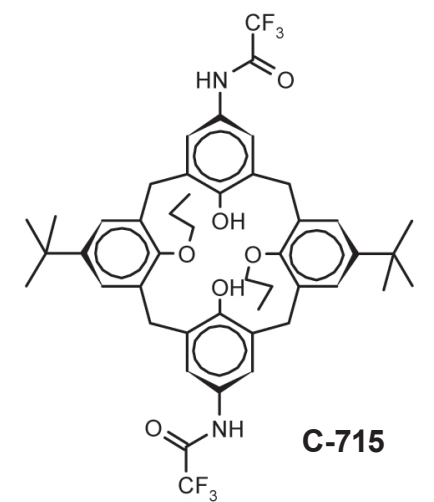

Fig. 1. The structural formulas of the studied calix[4]arene C-90 and its analogs (A) 



Fig. 1. Schematic representation of calix[4]arene molecule with numbered atoms (B); and schematic representation of calix[4]arene C-90 with numbered atoms $(\boldsymbol{C})$

incubation medium, $V_{\max }$ is maximal enzyme activity (at the saturating concentration of activator), $A$ is the activator concentration in the incubation medium [14]. Statistical processing of the obtained data was performed using standard methods of variation statistics [15]. Kinetic and statistical calculations were performed using MS Excel software.

In the experiments the following reagents were used: serum albumin, EGTA, EDTA, ATP, ascorbic acid, tris, dithiothreitol, acrylamide, (Sigma, USA), glycine (Merck, Germany), N,N'methylenebisacrylamide (Acros organics, Belgium) $\mathrm{N}, \mathrm{N}, \mathrm{N}^{\prime}, \mathrm{N}^{\prime}$-tetramethylenediamine (Reanal, Hungary), and other reagents (R-grade, Ukraine). The solutions were prepared in water purified on Crystal Bio System (Adrona, Latvia). The water conductance was less than $0.9 \mu \mathrm{S}$. The concentration of the divalent metal cations in solution was determined by Mohr method.

Computer modeling of the interaction between ligands (calix[4]arene C-90 and its analogs, model bindings) and receptor (myosin S1) was performed using AutoDock software, version 4.2 [16]. In our research, we used the enzyme three-dimensional structure with the $1 \mathrm{~b} 7 \mathrm{t}$ identifier in RSCB PDB [17]. Computer modeling of the calix[4]arene C-90 structural peculiarities was carried out using HyperChem 7.01. Molecular dynamics calculations were carried out by the MM2 method with the semiempirical methods (CNDO).
AutoDockTools software was used for preliminary "processing" of interacting molecules. 100 runs of Lamarkian genetic algorithms (population size 100 , the maximal number of energy evaluations 106) were conducted. To analyze and visualize the docking results we used the programs Chimera [18] and Yassara [19]. Calculation of the minimal total binding energy was performed considering Van der Waals forces, electrostatic and hydrophobic interactions, and hydrogen bonds. The optimal ligand positions in the complex "receptor-ligand" were determined according to the energy values obtained by docking software calculator for binding energy in complex "receptor-ligand". Thus, we selected a series of complexes with the lowest total energy, and then calculated the optimal geometry of the complexes and determined the most energetically preferred arrangement of the ligands in the space of myosin S1 binding domain.

\section{Results and Discussion}

In our previous studies, it was shown that $100 \mu \mathrm{M}$ calix[4]arene C-90 effectively activated (more that 2-fold) ATP hydrolysis catalyzed by swine myometrium actomyosin [7]. The enzyme activity of actomyosin complex is associated with the operation of the active center of myosin ATPase localized in the catalytic domain of myosin S1. The myosin head is the main catalytic and functional unit of myosin. Even in the isolated state, it retains the properties of 
native myosin, such as the ATPase activity and the ability to interact with actin.

The study of the effect of $100 \mu \mathrm{M}$ calix[4]arene C-90 on the ATP-hydrolase activity of myometrium myosin S1 showed that myosin head, similar to actomyosin complex, activated enzyme ATP hydrolysis, and the activating effect was $76 \pm 23 \%$ compared to control (without the addition of calix[4]arene) taken as $100 \%$. Greater effect of calix[4]arene C-90, compared to myosin S1, on the ATPase activity of myometrium actomyosin complex may be account for the presence of actin and regulatory proteins in the complex, which activate ATP hydrolysis and can probably be affected by calix[4]arene. The calix[4]arene C-90 influence on the actomyosin ATPase activity can be also realized owing to its ability to bind to the myosin head. That is, it was assumed that one of the targets of the calix[4]arene C-90 action on the contractile complex is myosin S1.

To identify the substituents, which are responsible for the calix[4]arene C-90 activating effect on the myosin head ATPase, we investigated the influence of structurally similar to C-90 calix[4]arenes: C-956, C-957, C-960, C772, C-716, C-715, as well as the calix[4]arene cup itself without substituents (compound C-150) and the model compound M-1 on the ATP hydrolysis catalyzed by myosin S1 (Fig. 1).

The structural formulas of calix[4]arene C-90 and its analogs are presented in Fig. 1.

The obtained results have demonstrated (Fig. 2) that calix[4]arene cup C-150 without substituent groups at the upper rim at a concentration of $100 \mu \mathrm{M}$ practically did not affect the ATPase activity of myosin S1. Model non-macrocyclic compound M-1 at a concentration of $100 \mu \mathrm{M}$ tended to slight activation of ATP hydrolysis catalyzed by myometrium myosin S1 compared to the control (without the addition of calix[4]arenes).

Calix[4]arene C-715 with two tert-butyl and two trifluoroacetamide groups at the upper rim at a concentration of $100 \mu \mathrm{M}$ practically did not affect ATP hydrolysis catalyzed by myosin S1 compared to control.

Other studied calix[4]arenes C-956, C-957, C-960, C-772, and C-716, which have at least two substituent groups inherent in calix[4]arene 90 at the upper rim, at a concentration of $100 \mu \mathrm{M}$ enhanced the ATPase activity of myosin S1.

It was also found that calix[4]arene C-772 exhibited the highest (after calix[4]arene C-90) activating effect. Calix[4]arene C-772 has two phenylsulfonyltrifluoroacetamidine and two tert-butyl groups at the upper rim. Two propoxy groups at the lower rim were substituted for two hydroxyl groups. This calix[4]arene at a concentration of $100 \mu \mathrm{M}$ activated myosin S1 catalyzed ATP hydrolysis by an average $60 \%$ compared to control.

Compound C-716 has two phenylsulfonyltrifluoroacetamidine groups and two tert-butyl groups and differ from calix[4]arene C-772 in geometric (proximal and distal) position of the substituents at the macrocyclic platform. Calix[4]arene C-716 at a

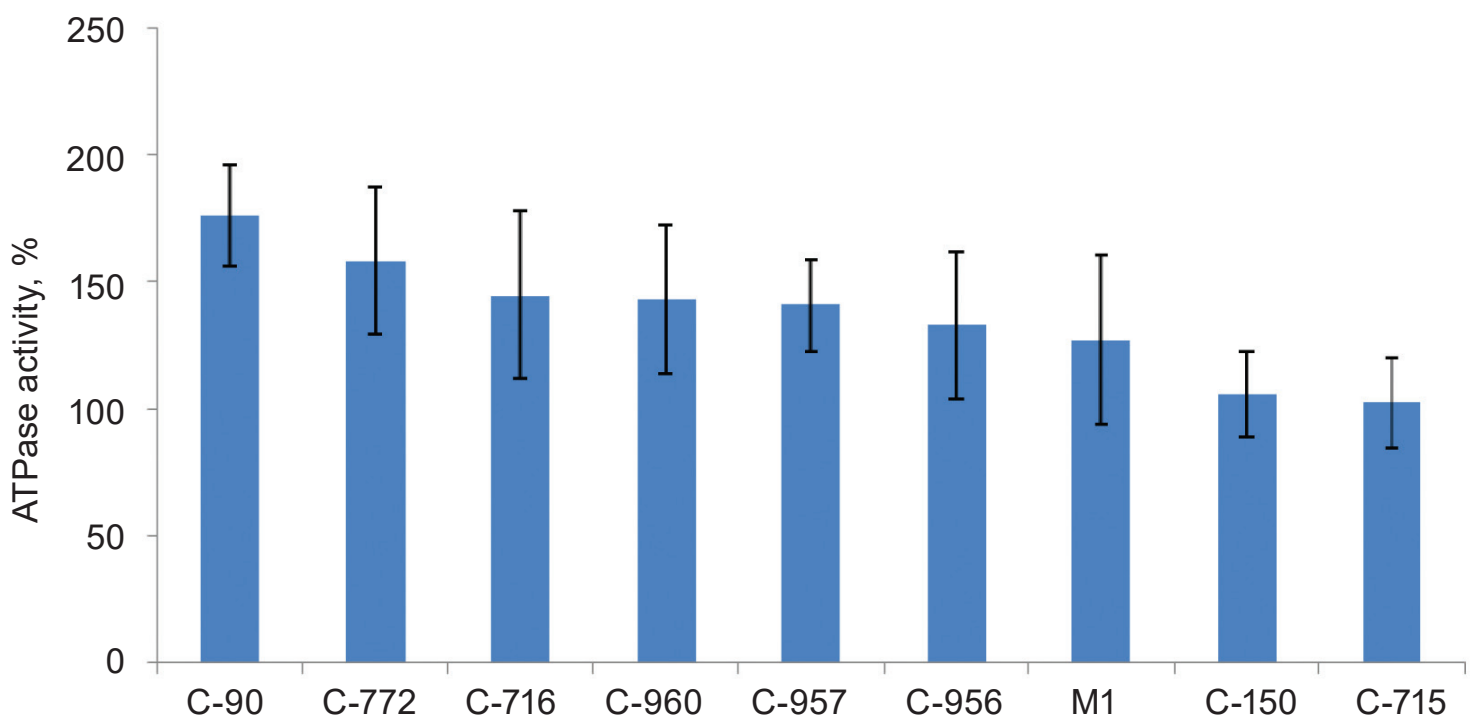

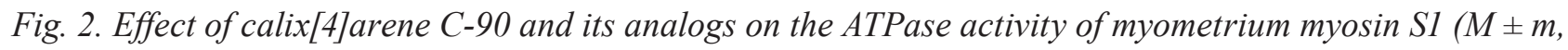
$n=6)$. The ATPase activity in the absence of calix[4]arenes was taken as $100 \%$ 
concentration of $100 \mu \mathrm{M}$ activated myosin S1 catalyzed ATP hydrolysis by almost $50 \%$ compared to the control.

ATPase activity of myosin S1 in the presence of $100 \mu \mathrm{M}$ of the compound C-960, which does not contain tert-butyl group at the macrocycle upper rim, increased by an average $43 \%$ compared to control.

The activating effect of the compound C-957, which has three N-phenylsulfonyltrifluoroacetamidine groups at the upper rim, at a concentration of $100 \mu \mathrm{M}$ was found to be on the average $40 \%$ relative to control.

The compound C-956, which differs by the presence of two lipophilic octyl groups at the lower rim, activated ATP hydrolysis by $32 \%$ at an average compared to the control.

In our further research, we focused on the study of the kinetic characteristics of the action of calix[4]arenes, which exhibited the greatest activating effect (more than 50\%) on the enzyme catalyzed ATP hydrolysis, namely, calix[4]arenes C-90 and C-772. To determine characteristic constants of the effect of these calix[4]arenes on the myosin ATP-hydrolase activity, we studied the dependence of ATPase activity on the calix[4] arenes concentrations $\left(10^{-5}-10^{-4} \mathrm{M}\right)$ (Fig. 3).

The values of apparent activation constants $K_{\mathrm{a}}$ and Hill coefficients $n_{\mathrm{H}}$ for calix[4]arenes C-90 and C-772 were almost the same (Table 1).
Tab le 1. Kinetics parameters of calix[4]arenes effect on the ATP-hydrolase activity of myometrium myosin $\mathrm{SI}$

\begin{tabular}{l|c|c}
\hline Calix[4]arenes & $\begin{array}{c}\text { Constant } \\
K_{\mathrm{a}}, \mu \mathrm{M}\end{array}$ & $\begin{array}{c}\text { Hill coefficient, } \\
n_{\mathrm{H}}\end{array}$ \\
\hline C-90 & $34.5 \pm 9.3$ & $2.2 \pm 0.3$ \\
C-772 & $34.3 \pm 1.6$ & $1.9 \pm 0.7$ \\
\hline
\end{tabular}

Comparing the obtained data as to the effect of the calix[4]arene C-90 structural analogs on the ATP hydrolysis catalyzed by myosin $\mathrm{S} 1$, it should be noted that the activating effect of these calix[4]arenes is defined by the structure of the macrocycle upper rim. Calix[4]arene C-90 analogs, which contain phenylsulfonyltrifluoroacetamidine groups at the macrocycle upper rim, activated the myosin S1 ATPase. Propoxy groups at the lower rim of calix[4]arenes C-772, C-716, C-960 and C-957 and octyloxy groups at the lower rim of calix[4]arene C-956, which are responsible for higher hydrophobicity of these compounds compared to calix[4]arene C-90, had a small effect on the ability of these calix[4]arenes to activate the myosin S1 catalyzed ATP hydrolysis. Amid all studied calix[4]arenes (except C-150 and M-1), only calix[4]arene C-715, which contains trifluoroacetamide groups instead of phenylsulfonyltrifluoroacetamidine groups, did not exhibit the activating effect.

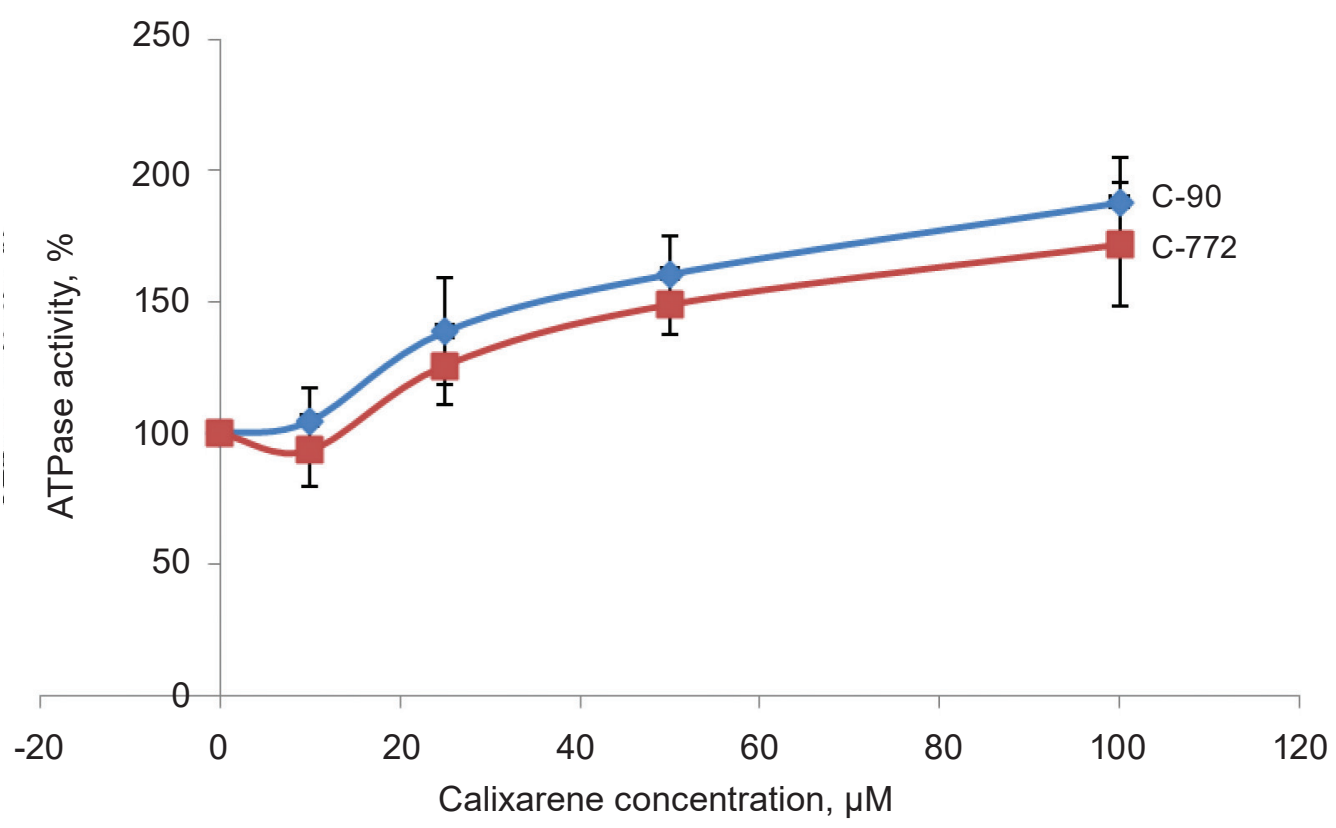

Fig. 3. Concentration dependence of the effect of calix[4]arenes C-90 and C-772 on the ATPase activity of myometrium myosin $S 1(M \pm m, n=5)$. The ATPase activity without addition of calix[4]arenes was taken as $100 \%$ 
Thus, phenylsulfonyltrifluoroacetamidine residues at the upper rim of calix[4]arene C-90 and its studied analogs are most likely to define their activating effect on the ATPase activity of myosin S1.

Interestingly, the calix[4]arene C-90 affected differently the activity of important enzymes involved in the functioning of the uterus SM and related to providing energy for its contraction (myosin ATPase), as well as the maintenance of intracellular ion homeostasis (plasma membrane ATPase). Thus, the specific enzyme activities of $\mathrm{Mg}^{2+}$-independent $\mathrm{Ca}^{2+}$-dependent ATPase and $\mathrm{Mg}^{2+}$-dependent $\mathrm{Na}^{+}, \mathrm{K}^{+}$-ATPase and $\mathrm{Mg}^{2+}$-ATPase of plasma membranes are not sensitive to the action of calix[4]arene C-90 [8]. At the same time, this compound at a concentration of $100 \mu \mathrm{M}$ inhibited effectively the activity of $\mathrm{Ca}^{2+}, \mathrm{Mg}^{2+}$-ATPase localized at the same membrane structure [8]. As it was shown in our study the calix[4]arene C-90 effectively activates the ATPase activity of myosin S1. Different susceptibility of ATPases of the contractile protein and plasma membrane of uterus myocytes to the calix[4]arene C-90 action can be attributed to their structural and functional peculiarities related to the role of these enzyme systems in myocytes. This fact should be borne in mind when studying the calix[4]arene C-90 influence on the contractile and electrical activity of myometrium cells.

To understand the molecular mechanisms of calix[4]arene C-90 the activating effect on myometrium myosin S1 catalyzed ATP hydrolysis, we performed computer modeling of the interaction between this compound and the S1. First, we searched for the optimal conformations of the calix[4]arene C-90 molecule using molecular mechanics (force field MM2). At that, some energy-minimized conformers were selected. The total energy of these structures was recalculated using the semi-empirical method (CNDO field) and then one structure with the lowest total energy was chosen.

The total energy of cali[4]arene C-90 after the "minimizing" was $410.6 \mathrm{kcal} / \mathrm{mol}$. It was a coneshaped conformation with small deviations in the positions 5 and 28 of the calix[4] arene's "cup". The distance between nearest oxygen atoms of propoxy residues at the lower rim was about $0.3 \mathrm{~nm}$. The phenyl moieties of the two substituents extended from the $\mathrm{C} 10$ and $\mathrm{C} 13$ atoms of the calix[4]arene's C-90 upper rim were arranged distally. Moreover, these substituents are located almost orthogonal to the macrocycle plane and easily accessible to inter- molecular interactions. At the same time, phenyl moieties of two other substituents at the upper rim extended from the $\mathrm{C} 5$ and $\mathrm{C} 28$ atoms are aligned in parallel.

We also developed three-dimensional models of calix[4]arene C-90 analogs and performed "minimization" of their total energy. We obtained the following values $(\mathrm{kcal} / \mathrm{mol})$ : C-715 - 272.2, C-716 293.7, C-772 - 278.5, C-956 - 417.3, C 957 - 367.2, C-960 - 286.4, M-1 - 49.6, C-150 - 104.6. It is obvious that with the increasing of the complexity of calix[4]arene structures their total minimal energy increases.

Development of three-dimensional model of calix[4]arene C-90 and "minimization" of its total energy enabled us to perform the computer modeling of potential sites of interaction between calix[4]arene C-90 and myosin S1. Also, we studied calix[4]arene C-715 with two tert-butyl and two trifluoroacetamide groups at the upper rim, calix[4]arene C-150, which is calix[4]arene cup itself without any functional groups, and non-macrocyclic model compound $\mathrm{M}-1$. The presence of binding sites at the studied ligands with S1 was confirmed by the values of the calix[4]arenes minimal binding energy and the amino acid environment. Given the size, geometric conformation and the presence or absence of certain substituent groups, it was expected that the calix[4]arenes C-90 and C-715 would have different affinity for the myosin S1 binding sites, and that the ligand-binding sites of the studied compounds would be formed with the involvement of different amino acid residues of the polypeptide chain.

It is known that myosin active center is formed with participation of: seven-stranded $\beta$-sheet linked with P-loop (Gly176-Lys187), switch 1 (amino acid residues Gly230-Phe243) and switch 2 (amino acid residues Ile461-Ser471), and $50 \mathrm{kDa}$ "upper" subdomain, relay (amino acid residues Leu475-Glu506) and converter (amino acid residues Phe716-Glu772), which are shown to be important for binding, coordination and the process of ATP hydrolysis. These structures are also involved in and spreading the conformational changes from myosin ATP-hydrolase center to the actin-binding site, affecting the position of myosin regulatory domain and its movement relative to actin filaments $[2,3]$.

P-loop (phosphate-binding loop) is a glycinerich motif with conserved Lys182 residue that transfers a charge +1 and forms hydrogen bonds with the oxygen of $\beta$ - and $\gamma$-phosphates of ATP. Ser178 
and Thr186 contain polar side chains, which facilitate interaction with the substrate. Thr186 stabilizes $\gamma$-phosphate by a hydrogen bond and oxygen of Thr186 hydroxyl reacts with $\mathrm{Mg}^{2+}$, essential for ATP binding and hydrolysis. Glu187 provides additional contact with Mg-ATP.

P-loop does not undergo substantial conformational changes upon binding and further hydrolysis of ATP, whereas the conformation of the switches 1 and 2 is dependent to a great extent on the presence or absence of nucleoside triphosphate $\gamma$-phosphate [2]. Switches 1 and 2 also contain a large number of reactive groups. The conserved switch 1 contains three residues with side polar chains (Asn237, Ser240, and Ser241) [20]. Switch 2 has three universal conserved residues, two of which (Asp460 and Glu465) transfer a formal charge 1 [2]. The salt bridge between Arg219 of switch 1 and Glu465 of switch 2 prevents the release of the ATP hydrolysis products at the myosin active site up to the moment when myosin head binds to the actin. It is assumed that Glu465 of the smooth muscle myosin plays important role in the positioning of the water molecule in the active site of the nucleophilic attack on the ATP $\gamma$-phosphate [1].

Given the complex structure of calix[4]arene C-90, which contains both the hydrophilic amidine and hydrophobic phenyl groups at the upper rim, as well as its large size, at first, it was necessary to analyze myosin S1 surface for possible binding sites (Fig. 4, 1). In so doing we primarily considered "cavity" close to the myosin S1 active site (Fig. 4, 2). Calix[4]arene C-715 was taken as a comparison pattern.

It was found that calix[4]arene C-90 can be complexed with the enzyme in the area, which is structurally close to the high-affinity binding site of $\mathrm{Mg}^{2+}$, which is involved in ATP binding and catalysis of its hydrolysis. This myosin S1 site is close to the switch 2 and contacts with the switch 1 and P-loop, near to the relay helix. Under these conditions two substituent groups (1 and $\mathbf{2})$ at the upper rim of calix[4]arene C-90 interact with the amino acid residues in the areas closest to the nucleoside binding center. The other two groups ( 3 and $\mathbf{4}$ ) and calix[4]arene C-90 cup are fixed in the "cavity" of the myosin S1motor domain farther away from the ATPase site by some amino acid residues. In particular, the phenyl moieties of the calix[4]arene cup and the side groups of calix[4]arene C-90 are fixed by the residues of aromatic amino acids Tyr274, Tyr282, Phe464, Phe467, and Phe469.

It is obvious from the obtained experimental data that the phenylsulfonyltrifluoroacetamidine clusters of calix[4]arene C-90 and its analogs are likely to define their activating effect on ATPase of myosin S1. Therefore, it was essential to identify, with which amino acid residues of the enzyme, the
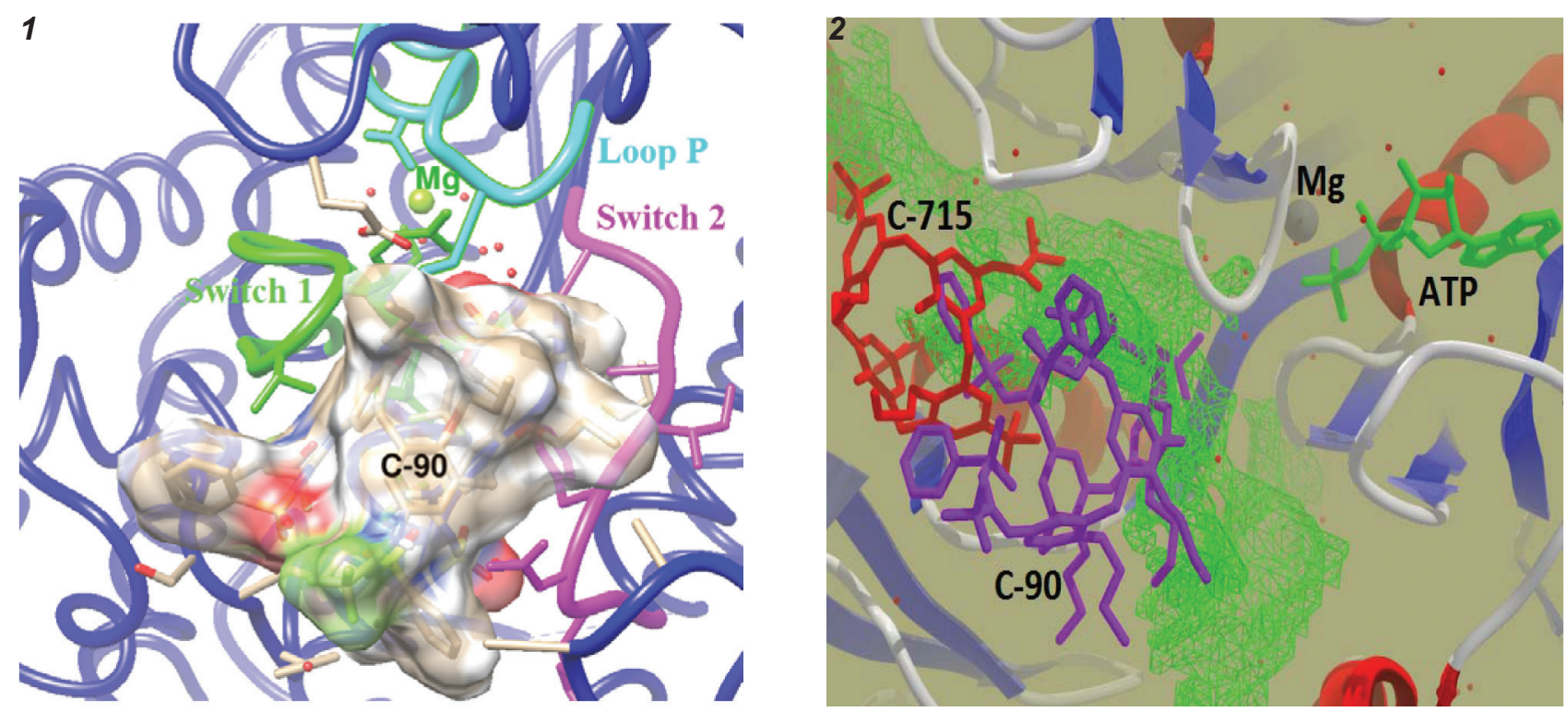

Fig. 4. 1 -Docking of calix[4]arene C-90 into myosin S1 molecule. Colors in the figure: P-loop-turquoise, switch 1 -green, switch 2 - pink. 2 - Analysis of functionally active site of myosin to identify the most likely binding region of calix[4]arenes $C-90$ (purple) and C-715 (red); cavities are marked by the green net 
calix[4]arene C-90 phenylsulfonyltrifluoroacetamidine groups can interact. By docking of calix[4]arene C-90 into myosin subframent-1, it was found that one of the residue 1 extends from $\mathrm{C} 13$ of calix[4]arene cup. Under these conditions nitrogen (N33) of this residue reacts with Thr235, and nitrogen (N59) - with Thr234 and Glu279, oxygen (O62) interacts with $\operatorname{Arg} 242$, and oxygen (O63) interacts with Arg236. The phenyl ring of this cluster is in the steric interaction with Phe464. Moreover, this phenylsulfonylamidine residue may directly affect functionally important residue Ser178, containing polar side chain, which facilitates interaction with the substrate [20]. Other functionally important phenylsulfonyltrifluoroacetamidine residue 2 extends from C10 of calix[4]arene cup. Nitrogen (N82) of this residue interacts with Glu465, oxygen (O94) interacts with Gln276. The phenyl ring of the residue is in the steric interactions with Tyr274 (here, the steric effect is a factor that includes the influence of calix[4]arene and amino acids conformation and/or spatial arrangement on their interaction).

Two other phenylsulfonyltrifluoroacetamidine residues $\mathbf{3}$ and $\mathbf{4}$, presumably, perform a secondary but yet important function. They help calix[4]arene C-90 to take the most optimal conformational position. Under these conditions the positively and negatively charged atoms of this residues interact with polar side chains of amino acid residues - Arg271, Arg570, Asn572, Ser277, Asp468 and Glu675 (Fig. 5, 1). However, we cannot exclude that these residues

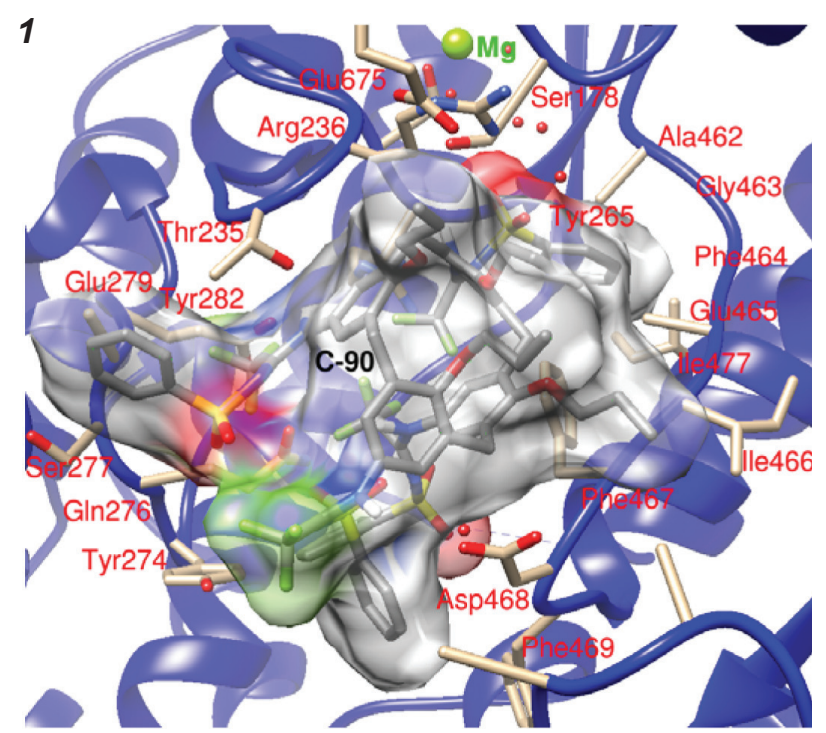

interact with allosteric regions of myosin S1 and affect the operation of the active center.

Amino acid residues Ser178, Arg236, Gln276, Glu675, Glu279, Glu465 and two water molecules (in Fig. 6 marked as small red spheres), involved in the enzyme structure stabilization, can form hydrogen bonds. Fragments of the calix[4]arene cup are arranged in the space formed by the amino acid residues: Phe464, Phe467, Phe469, involved in $\pi-\pi$ stacking interactions; and the residues: Thr234, Thr235, Ser277, Ile466, and Ile477, involved in steric interactions.

Thus, binding of calix [4] arene C-90 with myosin S1 occur owing to hydrogen bonds, $\pi-\pi$ stacking interactions between aromatic rings of the calix[4]arene cup and aromatic rings of hydrophobic amino acids of myosin head, as well as steric interactions. The presence of the hydrophobic platform and the side residue phenyl groups at the upper rim of calix[4]arene C-90 can facilitate its fixing on the enzyme hydrophobic sites. Some amino acid residues, involved in the fixing of the side groups of the calix[4]arene C-90 upper rim, are part of the myosin $\mathrm{S} 1$ seven-strand $\beta$-sheet and bound to it polypeptide regions of switch 1 and switch 2 .

We also performed computer modeling of the interaction between calix[4]arene C-715 and ligand-binding sites of myosin S1 (Fig. 5, 2). Hydrophobic cup of calix[4]arene C-715 is fixed by hydrophobic cluster - aromatic amino acid residues Phe467, Phe469, Phe472, and Tyr274. Some of these

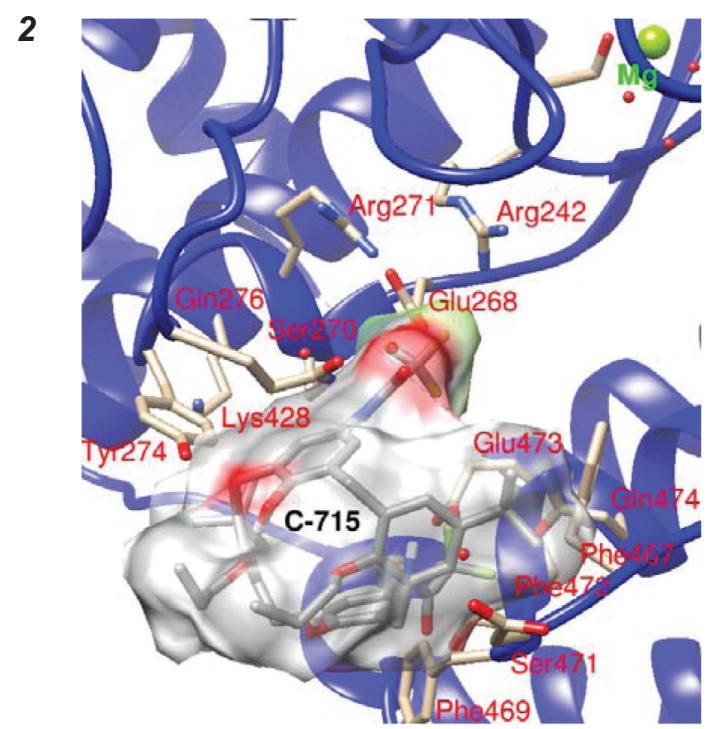

Fig. 5. The structure of the calix[4]arene C-90 (1) and the calix[4]arene C-715 (2) complexes with amino acid residues of myosin S1 (obtained by docking of the ligand into myosin S1) 
amino acid residues are involved in the fixing of calix[4] arene C-90 cup. However, configuration of calix[4]arene C-715 in the structure of myosin S1 differs from calix[4]arene C-90 (Fig. 4, 2), which can be a result of the lack of the significant substituent groups of the calix[4] arene C-90 upper rim. Fixation of the tert-butyl and trifluoroacetamide groups of calix[4]arene C-715 in this region occur owing to such amino acid residues as Lys428, Ser270, Ser471, Ser590, and Ile466. Positively and negatively charged atoms of calix[4] arene C-715 interact with polar side chains of amino acid residues - Arg271, Gln276, Gln473, and Glu474.

The obtained values of the total energy (Table 2) for each amino acid residue of myosin S1, which interacts with calix[4]arenes C-90 and C-715, indicate the ability of these residues to interact with the studied ligands, as well as the distance, in which these interactions occur, and geometric parameters of these interactions. Here, the geometric parameters of interaction mean the arrangement of calix[4]arene and the protein amino acid residues relative to each other that affects the conformation of this interaction and the distance between the interacting sites of calix[4]arene and amino acids, that in turn affects the energy parameters. High energy value for a particular amino acid residue may indicate a stronger bond between the studied calix[4]arene and the corresponding residue.

As it can be seen (Table 2), the number of myosin S1 amino acid residues that interact with the substituent groups of calix[4]arene C-90 was significantly greater than that of interacting with substituent groups of calix[4]arene C-715 that correlates with a smaller size of the latter. Moreover, two amino acid residues (Arg271 and Gln276) were revealed to be common for fixation of the substituent groups of both calix[4]arenes. When comparing their energy characteristics, it is evident that Arg271 and Gln276 are located at the greater distance from the functional groups of calix[4]arene C-715 compared to calix[4] arene C-90 that can cause the different ability of calix[4]arenes to interact with these amino acid residues. Obviously, the stronger binding of myosin subragment- 1 with Arg271 and Gln276 of calix[4]arene C-90 occurred.

To analyze the obtained results we investigated the calix[4]arenes C-90 and C-715 binding sites with myosin $\mathrm{S} 1$ as to hydrophobic and hydrophilic environment, as well as electrostatic interactions

Table 2. The energy characteristics of the myosin S1 amino acid residues, which interact with the substituent groups of calix[4]arenes $C-90$ and C-715 (results of docking of the studied ligands)

\begin{tabular}{c|c|c|c|c|c}
\hline \multicolumn{2}{c}{ C-90 } & \multicolumn{3}{c}{ C-715 } \\
\hline Amino acid & No residue & $\begin{array}{c}\text { Total energy, } \\
\text { (relative units) }\end{array}$ & Amino acid & No residue & $\begin{array}{c}\text { Total energy, } \\
\text { (relative units) }\end{array}$ \\
\hline Arg & 236 & 16.7887 & Arg & 271 & 3.43011 \\
Arg & 242 & 5.55218 & Gln & 276 & 7.7219 \\
Arg & 271 & 0.307643 & Gln & 473 & 1.70776 \\
Arg & 570 & 0.51949 & Glu & 474 & 5.6253 \\
Asn & 572 & 5.27188 & Ile & 466 & 0.783888 \\
Gln & 276 & 4.65522 & Lys & 428 & 0.406284 \\
Glu & 279 & 2.1556 & Ser & 270 & 3.07315 \\
Glu & 465 & 1.90631 & Ser & 471 & 6.4307 \\
Glu & 675 & 8.24882 & Ser & 590 & 0.800814 \\
Phe & 464 & 2.56445 & & & \\
Ser & 178 & 1.80049 & & & \\
Ser & 277 & 9.63614 & & & \\
Thr & 234 & 2.35446 & & & \\
Thr & 235 & 8.39194 & & & \\
Tyr & 274 & 4.47047 & & & \\
\hline
\end{tabular}



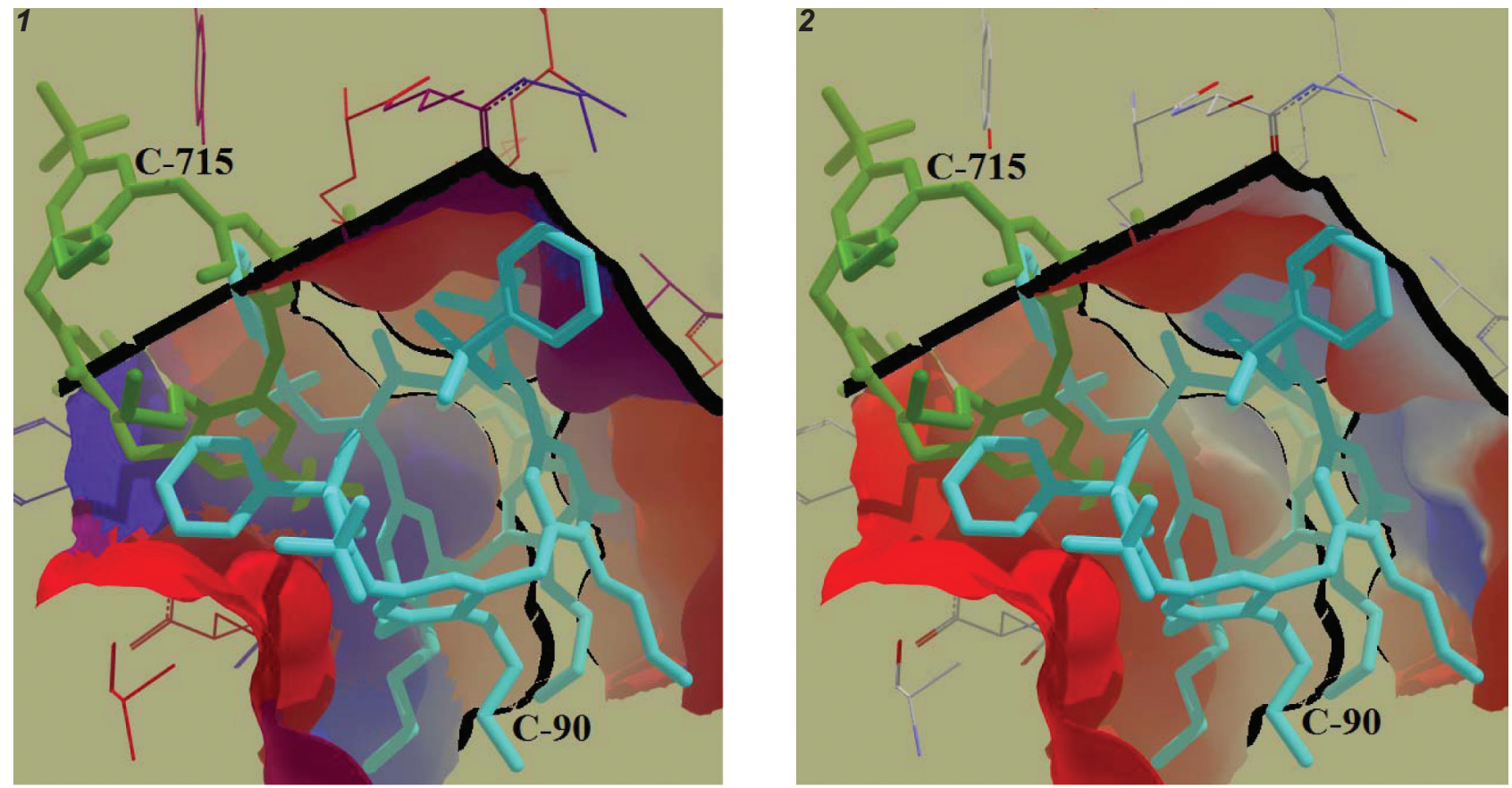

Fig. 6. Analysis of the binding sites of calix[4]arenes C-90 (turquoise) and G-715 (green) with myosin S1 in terms of $\mathbf{1}$-hydrophobic (red) and hydrophilic (blue) environment; $\mathbf{2}$-electrostatic environment: red is positive, blue is negative

(Fig. 6). Presumably, the presence of four complex as to their composition side clusters at the upper rim of calix[4]arene C-90, compared to two tert-butyl and trifluoroacetamide groups of calix[4]arene C-715, enabled calix[4]arene C-90 to interact with the large number of functionally important amino acid residues and thereby affect ATP hydrolysis. Our research showed that the quite large calix[4]arene platform is important in the direct interaction with the enzyme, while substitutions in the upper rim define a vector, in which calix[4]arene is directed.

We also investigated the possible interaction of calix[4]arene cup C-150 and model non-macrocyclic compound M-1 with myosin S1. It was found that calix[4]arene C-150 is most likely to interact with the enzyme in the area, which is rich in hydrophobic amino acid residues. In this case, calix[4]arene C-150, in contrast to calix[4] arene C-90, is located farther from the enzyme active center, and its hydrophobic cup is fixed by the following amino acid residues: Phe467, Phe469, Glu473, Thr231, Ser237, and Asp320. The absence of the side cluster limits the ability of calix[4]arene C-150 to interact with the enzyme active center and influence on its activity.

The obtained experimental data as to the model fragment M-1, which is $1 / 4$ part of calix[4] arene C-90 and tends to activate ATP hydrolase of myosin S1, are consistent with the results of computer modeling. It was shown that M-1 is able to interact with some amino acid residues, involved in fixation of calix[4]arene C-90 (data are not shown). The presence of phenylsulfonyltrifluoroacetamidine cluster and hydrophobic phenol ring in the structure of M-1 facilitates interaction between M-1 and amino acid residues of S1. However, the interaction of one substituent group of calix[4]arene C-90, which is in the M-1 structure, with amino acid residues of myosin S1 probably does not refer to all sites of the enzyme related to the calix[4] arene C-90 activating the effect on ATPase.

The hydrolysis of ATP is accompanied by conformational changes in the myosin S1 structural elements, which form its active center [20, 21]. First of all, it concerns important for binding, coordination and realization of ATP hydrolysis P-loop, switch 1 and switch 2. The found myosin S1 amino acid residues, which can interact with substituent groups of calix[4]arene C-90, belong to the mentioned above structures. Calix[4]arene C-90 interacting with the three main loops of the myosin ATP- hydrolase site (Fig. 4,1 ) is likely to influence the conformational flexibility of the enzyme structure and to stabilize the conformation of these loops in the position most favorable for dissociation of Pi from $\mathrm{Mg}$-ADP com- 
plex, and thus activate ATP hydrolysis. In our study using docking, we found that phenylsulfonyltrifluoroacetamidine residue of calix[4]arene C-90, attached to $\mathrm{C} 10$ of its cup, interacts with Ser178 of myosin S1 phosphate-binding loop. The polar side chain of Ser178 facilitates interaction of ATP with the myosin active center [1] that contributes to ATP hydrolysis. We have also shown that nitrogen (N82) of phenylsulfonyltrifluoroacetamidine residue extended from C4 of calix[4]arene C-90 cup (Fig. 5, 1), takes part in the interaction with Glu465 of myosin S1. It is known that Glu465 in the structure of smooth muscle myosin is essential for the water molecule assembly in the enzyme active center for the nucleophilic attack on gamma-phosphate of ATP [1]. Probably, upon binding of calix[4]arene C-90 with Glu465, the "active" water molecule changes its position in the myosin active center, more intensively attacking ATP macroergic bonds and positively affecting nucleosidetriphosphate hydrolysis catalyzed by myo$\sin \mathrm{S} 1$.

Thus, calix[4]arene C-90 and its analogs, namely calix[4]arenes: C-956, C-957, C-960, C-772, and C-716, which have at least two functional phenylsulfonyltrifluoroacetamidine groups at the upper rim, at concentration of $100 \mu \mathrm{M}$, activated ATPase of the myometrium myosin S1; whereas the calix[4]arene cup without substituent groups C-150 and the model non-macrocyclic compound M-1 did not exhibit an activating effect. Computer modeling revealed that the phenylsulfonyltrifluoroacetamidine groups of calix[4] arene C-90, which is likely to define its activating effect on the enzyme, reacted with the important for binding, coordination and realization ATP hydrolysis amino acid residues of the myosin S1 polypeptide chain.

This work was financially supported by the State Targeted Scientific and Technical Program "Nanotechnology and nanomaterials" No 0110U005970, the Targeted Comprehensive Interdisciplinary Research Program of NAS of Ukraine "Molecular and cellular biotechnology for medicine, industry and agriculture", the Targeted Comprehensive Interdisciplinary Research Program of NAS of Ukraine "Fundamentals of molecular and cellular biotechnology" No 0110U005971, the Targeted Comprehensive Fundamental Research Program of NAS of Ukraine "Molecular design, synthesis and biological research of calix[4]arene regulators of intracellu- lar calcium homeostasis in the smooth muscle under normal conditions and upon contractile dysfunction" No 0112 U004262.

\section{КАЛІКС [4]АРЕН С-90 ТА ЙОГО АНАЛОГИ АКТИВУЮТЬ АТР- ГІДРОЛАЗНУ АКТИВНІСТЬ СУБФРАГМЕНТА-1 МІОЗИНУ MIOMETPIЯ}

\section{Р. Д. Лабинцева ${ }^{l}$, О. В. Бевза $a^{l}$ К. В. Литвин ${ }^{1}$, М. О. Боровик', Р. В. Родік², В. І. Кальченко C. O. Костерін ${ }^{l}$}

${ }^{1}$ Інститут біохімії ім. О. В. Палладіна НАН України, Київ;

e-mail: labyntseva@biochem.kiev.ua;

${ }^{2}$ Інститут органічної хімії НАН України, Київ; e-mail:vik@ioch.kiev.ua

Багато патологій репродуктивної системи в жінок $є$ наслідком порушення скоротливої функції гладенького м'яза матки (міометрія). У зв'язку з цим виникає потреба в розробленні ефективних методів корекції таких порушень. Міозинова АТРаза перетворює хімічну енергію, депоновану в макроергічних зв'язках АТР, у механічну зі спрямованим рухом і локалізована в каталітичному домені субфрагмента-1 міозину. Показано, що калікс[4]арен C-90 та його структурні аналоги, які функціоналізовані на верхньому вінці макроциклу чотирма або принаймні двома $\mathrm{N}$-фенілсульфонілтрифторацетамідиновими групами, активують гідроліз АТР, каталізований субфрагментом-1 міозину міометрія. Методом комп'ютерного моделювання встановлено, що $\mathrm{N}$-фенілсульфонілтрифторацетамідинові групи калікс[4]арену C-90 взаємодіють 3 амінокислотними залишками поліпептидного ланцюга субфрагмента-1 міозину, важливими для зв'язування, координації та здійснення процесу гідролізу АТР. Одержані результати у подальшому можуть бути використані в дослідженнях, спрямованих на використання калікс[4]арену C-90 та його аналогів як сполук, здатних ефективно нормалізувати скоротливу гіпофункцію міометрія.

К л юч о в і слов а: субфрагмент-1 міозину, АТРазна активність, калікс[4]арен С-90, докінг, гладенькі м'язи, матка. 


\section{КАЛИКС [4]АРЕН С-90 И ЕГО АНАЛОГИ АКТИВИРУЮТ АТР- ГИДРОЛАЗНУЮ АКТИВНОСТЬ СУБФРАГМЕНТА-1 МИОЗИНА МИОМЕТРИЯ}

\author{
Р. Д. Лабыниева ${ }^{l}$, А. В. Бевза ${ }^{l}$, \\ Е. В. Литвин ${ }^{l}$, М. А. Боровик', Р. В. Родик ${ }^{2}$, \\ В. И. Кальченко ${ }^{2}$, С. А. Костерин ${ }^{I}$
}

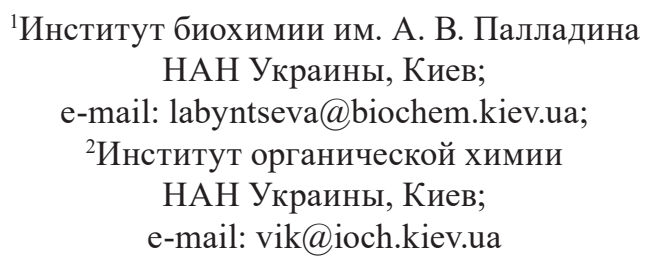

Многие патологии репродуктивной системы у женщин являются следствием нарушений сократительной функции гладких мышц матки (миометрия). В связи с этим возникает необходимость разработки эффективных методов коррекции таких нарушений. Миозиновая АТРаза превращает химическую энергию, депонированную в макроэргических связях АТР, в механическую с направленным движением, и локализована в каталитическом домене субфрагмента-1 миозина. Показано, что каликс[4]арен C-90 и его структурные аналоги, функционализованные по верхнему ободу макроцикла четырьма или по крайней мере двумя N-фенилсульфонилтрифторацетамидиновыми группами, активируют гидролиз АТР, катализированный субфрагментом-1 миозина миометрия. Методом компьютерного моделирования установлено, что $\mathrm{N}$-фенилсульфонилтрифторацетамидиновые групппы каликс[4]арена С-90 взаємодействуют с аминокислотными остатками полипептидной цепи субфрагмента-1 миозина, важными для связывания, координации и осуществления процесса гидролиза АТР. Полученные результаты в дальнейшем могут быть использованы в исследованиях, направленных на использование каликс[4]арена С-90 и его аналогов в качестве соединений, способных эффективно нормализовать сократительную гипофункцию миометрия.

К л ю че в ы е с л о в а: субфрагмент-1 миозина, АТРазная активность, каликс[4]арен С-90, докинг, гладкие мышцы, матка.

\section{References}

1. Burghardt TP, Neff KL, Wieben ED, Ajtai K. Myosin individualized: single nucleotide polymorphisms in energy transduction. $B M C$ Genomics. 2010; 11: 172.

2. Decarreau JA, James NG, Chrin LR, Berger CL. Switch I closure simultaneously promotes strong binding to actin and ADP in smooth muscle myosin. J Biol Chem. 2011; 286(25): 2230022307.

3. Bloemink MJ, Melkani GC, Bernstein SI, Geeves MA. The Relay/Converter Interface Influences Hydrolysis of ATP by Skeletal Muscle Myosin II. J Biol Chem. 2016; 291(4): 1763-1773.

4. Wray S. Insights from physiology into myometrial function and dysfunction. Exp Physiol. 2015; 100(12): 1468-1476.

5. Rodik RV, Boyko VI, Kalchenko VI. Calixarenes in bio-medical researches. Curr Med Chem. 2009; 16(13): 1630-1655.

6. Nimse SB, Kim T. Biological applications of functionalized calixarenes. Chem Soc Rev. 2013; 42(1): 366-386.

7. Labyntseva RD, Slinchenко NM, Veklich TO, Rodik RV, Cherenok SO, Boiko VI, Kalchenko VI, Kosterin SO. Comparative investigation of calixarenes influence on $\mathrm{Mg}^{2+}$ dependent ATP-hydrolase enzymatic systems from smooth muscle cells of the uterus. Ukr Biokhim Zhurn. 2007; 79(3): 44-54. (In Ukrainian).

8. Veklich TO, Shkrabak AA, Mazur YuYu, Rodik RV, Kalchenko VI, Kosterin SO. Kinetics of inhibitory effect of calix[4]arene C-90 on activity of transporting plasma membrane $\mathrm{Ca}^{2+}$, $\mathrm{Mg}^{2+}$-ATPase of smooth muscle cells. $U k r$ Biochem J. 2014; 86(5): 37-46. (In Ukrainian).

9. Labyntseva RD, Bobrovska OM, Chunikhin OJu, Kosterin SO. Influence of heavy metal ions on the ATPase activity of actomyosin complex and myosin subfragment-1 from smooth muscle of the uterus. Ukr Biokhim Zhurn. 2011; 83(4): 8493. (In Ukrainian).

10. Suzuki H, Kondo Y, Carlos AD, Seidel JC. Effects of phosphorylation, MgATP, and ionic strength on the rates of papain degradation of heavy and light chains of smooth muscle heavy meromyosin at the S1-S2 junction. J Biol Chem. 1988; 263(22): 10974-10979. 
11. Schägger H, von Jagow G. Tricine-sodium dodecyl sulfate-polyacrylamide gel electrophoresis for the separation of proteins in the range from 1 to $100 \mathrm{kDa}$. Anal Biochem. 1987; 166(2): 368-379.

12. Chen PS, Toribara TY, Warner H. Microdetermination of phosphorus. Anal Chem. 1956; 28(11): 1756-1758.

13. Rodik R, Boiko V, Danylyuk O, Suwińska K, Tsymbal I, Slinchenko N, Babich L, Shlykov S., Kosterin S., Lipkowski J., Kalchenko V. Calix[4]arenesulfonylamidines. Synthesis, structure and influence on $\mathrm{Mg}^{2+}$, ATP-dependent calcium pumps. Tetrahedron Letters. 2005; 46(43): 74597462.

14. Cornish-Bowden A. Fundamentals of Enzyme Kinetics, 2004. Portland Press, London, $3^{\text {rd }}$ edn. $422 \mathrm{p}$.

15. Kokunin VA. Statistical processing of data from a small number of experiments. Ukr Biokhim Zhurn. 1975; 47(6): 776-791. (In Ukrainian).

16. Cassidy CE, Setzer WN. Cancer-relevant biochemical targets of cytotoxic Lonchocarpus flavonoids: a molecular docking analysis. $J \mathrm{Mol}$ Model. 2010; 16(2): 311-326.

17. Houdusse A, Kalabokis VN, Himmel D, SzentGyörgyi AG, Cohen C. Atomic structure of scallop myosin subfragment S1 complexed with MgADP: a novel conformation of the myosin head. Cell. 1999; 97(4): 459-470.

18. Li L, Jose J, Xiang Y, Kuhn RJ, Rossmann MG. Structural changes of envelope proteins during alphavirus fusion. Nature. 2010; 468(7324): 705708.

19. Krieger E, Koraimann G, Vriend G. Increasing the precision of comparative models with YASARA NOVA - a self-parameterizing force field. Proteins. 2002; 47(3): 393-402.

20. Himmel DM, Gourinath S, Reshetnikova L, Shen Y, Szent-Györgyi AG, Cohen C. Crystallographic findings on the internally uncoupled and near-rigor states of myosin: further insights into the mechanics of the motor. Proc Natl Acad Sci USA. 2002; 99(20): 1264512650.

21. Minehardt TJ, Marzari N, Cooke R, Pate E, Kollman PA, Car R. A classical and ab initio study of the interaction of the myosin triphosphate binding domain with ATP. Biophys J. 2002; 82(2): 660-675.

Received 22.07.2016 